\title{
Are 40 years better than 55 ? An analysis of the reduction of forest rotation to cope with drought events in a Douglas fir stand
}

\author{
Nathalie Bréda ${ }^{1} \cdot$ Marielle Brunette $^{2}$ [D \\ Received: 3 September 2018 / Accepted: 1 March 2019 / Published online: 2 April 2019 \\ (C) INRA and Springer-Verlag France SAS, part of Springer Nature 2019
}

\begin{abstract}
- Key message Reduction of forest rotation is analyzed as a potential adaptation strategy for a Douglas fir stand to cope with drought-induced risk of forest decline. The methodology combines a water balance modeling and an economic approach. Results show that, from an economic perspective, adaptation (immediate or delayed) is always better than the absence of adaptation.

- Context Reduction of rotation length emerges as a potential adaptation strategy to cope with climate change.

- Aim The study aims to address the reduction of rotation length to deal with the drought-induced risk of forest decline taking a multidisciplinary approach.

- Methods We estimate probabilities and impacts of drought events quantified by water balance modeling and we evaluate, from an economic point of view, the reduction of rotation length to cope with the drought-induced risk of forest decline. We compare three different adaptation strategies at the economic level: absence of adaptation, immediate adaptation, and delayed adaptation. - Results Results suggest that immediate reduction of rotation length is associated with the best economic return, followed by delayed adaptation and, finally, by the absence of adaptation. This result is sensitive to the level of timber loss in the event of drought occurrence. If the loss of timber volume is higher than $48 \%$, then delayed adaptation may be preferable to immediate adaptation.

- Conclusion Beyond the specificities of the case study, this paper proposes a multidisciplinary approach to address adaptation strategies.
\end{abstract}

Keywords Adaptation $\cdot$ Economics $\cdot$ Climate change $\cdot$ Water balance $\cdot$ Risk of decline $\cdot$ Pseudotsuga menziesii

Handling Editor: Rasoul Yousefpour

Contributions: Marielle Brunette: economic calculation and writing of the article.

Nathalie Bréda: estimation of probabilities and impacts of drought, and writing of the article.

This article is part of the Topical Collection on Risk Analysis

Marielle Brunette

marielle.brunette@inra.fr

Nathalie Bréda

nathalie.breda@inra.fr

1 UMR 1137 INRA UL, Forest Ecology and Ecophysiology, INRA, 54280 Champenoux, France

2 Université de Lorraine, Université de Strasbourg, AgroParisTech, CNRS, INRA, BETA, 54000 Nancy, France

\section{Introduction}

Climate change through increasing temperatures and changes in water and disturbance regimes will have an impact on the majority of ecosystems and, especially, on the long-lived forest ecosystem (IPCC 2012, 2014). Indeed, due to the length of the investment period and the limited reversibility or plasticity of decisions, forests seem to be of particular interest to analyze adaptation options. Forest managers are accustomed to considering the long-term implications of their decisions (Keenan 2012). However, many management actions are now responding to much shorter-term economic or political imperatives. Some current management measures may continue to be suitable to respond to increasing pressures under climate change, whereas for other situations, new measures will be required. Adaptation to climate change involves assessing, mitigating, and controlling risks. Kolström et al. (2011) suggested that models are important to analyze risks, and that 
improved risk simulations are required to assess the effectiveness of alternative management options in mitigating disturbance impacts. This is the aim of the present research.

Given that a forest planted today will come to maturity and be ready to be harvested in 30 to 100 years, depending on the species, it will necessarily be exposed to future climatic hazards. However, since the increase in atmospheric $\mathrm{CO}_{2}$ concentrations may continue during the coming century, with an average temperature increase from 1.1 to $6.4{ }^{\circ} \mathrm{C}$, depending on the SRES hypothesis corresponding to more or less efficient mitigation of climate change, disturbance and water regimes may be modified (Pachauri et al. 2014). The productivity of forest ecosystems is severely constrained by water availability, and extreme drought events are known to induce largescale tree decline episodes in temperate forests (Bréda and Badeau 2008). As a consequence of soil water deficit, tree growth will be limited and gas exchanges restricted due to stomatal closure, and irreversible damage (needle fall, xylem embolism, dead branches, and roots) will occur in the event of extreme soil water shortage (Bréda et al. 2006). Climate change would then accentuate extreme drought events (IPCC 2012) and, in turn, lead to drought-induced dieback in forests, generating lower forest return.

In such a context, some adaptation actions are thus recommended to face increasing drought risk such as the reduction of rotation (Gottschalk 1995; Lindner et al. 2000; Spittlehouse and Stewart 2003). The rotation is the time from the establishment of a forest stand to its final felling. ${ }^{1}$ Indeed, from a forest management point of view, reducing the rotation is considered as a win-win option, diminishing both the time of exposure to drought events and the vulnerability of trees due to aging (Spiecker 2003; Bréda and Peiffer 2014). In addition, old trees are among the most vulnerable to drought (Becker and Lévy 1988; Archaux and Wolters 2006) so that avoiding long rotations seems to be a win-win option. However, some forest managers reject this option, fearing a loss of economic efficiency by selling timber with a smaller diameter, less total volume production, a more frequent incidence of planting costs, and a reduction in the provision of ecosystem services. Intuitively, one argument in favor of the reduction of the rotation length may be the less frequent costs of thinning. Consequently, owners question the implementation and the associated costs of such an adaptation option. The question is then: from an economic perspective, is the reduction of rotation a relevant forest adaptation strategy to cope with the future risk of dieback induced by drought event? This strategy is tested as an anticipative and planned adaptation option, and not a reactive one when an extreme drought event occurs.

From a biological point of view, the reduction of rotation has led to studies mainly focused on the link between rotation

$\overline{{ }^{1} \text { This definition }}$ applies for a normal forest. and carbon storage (Liski et al. 2001; Kaipainen et al. 2004). Less attention has been paid to the potential advantage of reducing rotation to improve tree resistance to perturbations, especially to drought events. It is known that hydraulic conductivity decreases with age and tree height (Woodruff et al. 2008), leading to an unstable equilibrium in tree water and carbon balance due to allometry adjustments to cope with stresses (McDowell et al. 2002; Kennedy et al. 2009). Moreover, tree vulnerability increases with age, especially because of interacting biotic and abiotic perturbations (Bréda and Peiffer 2014). Finally, tree growth and crown condition are impaired by aging (de Kort and Baas 1997): crown condition is firstly correlated to tree age, altitude, and drought stress, regardless of the species, as reported on the ICP forest monitoring network (de Vries et al. 2014). In France, thanks to the national forest health service database, we observed that more than $65 \%$ of drought-induced Douglas fir declines occurred in stands older than 30 years.

From an economic point of view, two types of literature are of interest. The first one deals with the impacts of risk on rotation. Thus, a stochastic forest stand value (Clarke and Reed 1989, 1990; Willassen 1998; Alvarez 2004; Chang 2005), stochastic timber price (Brazee and Mendelsohn 1988; Thomson 1992; Insley 2002; Insley and Rollins 2005), or interest rate variability (Alvarez and Koskela 2003, 2005) lengthens the optimal rotation period. To the contrary, storm risk has a tendency to shorten rotation length (Haight et al. 1995; Price 2011; Rakotoarison and Loisel 2017). In the same vein, fire risk reduces the rotation length compared to a deterministic situation, both theoretically (Reed 1984; Martell 1994; Amacher et al. 2005) and empirically (Kuuluvainen and Tahvonen 1999; Englin et al. 2000). The article of Newman (2002) provided an interesting overview of the literature on this topic. This last result is thus discussed with regard to amenity values (Englin et al. 2000), changes in fire risk over time (Stollery 2005), and risk aversion (Alvarez and Koskela 2006), among others. However, this literature only concentrates on fire risk and storm, which have characteristics different from drought risk. Indeed, a drought risk occurrence has a lower direct impact on a forest stand than fire or storm, but this impact lasts several years and increases over time. In addition, this literature is not interested in the impact of climate change on the risk, although it is well known that climate change will increase the intensity and frequency of natural events, in particular, drought events.

The second literature deals with forest adaptation via an economic approach. First, Hanewinkel et al. (2010) and Brunette et al. (2014) focused on species shifts as an adaptation option to deal with climate change. Hanewinkel et al. (2010) evaluated the economic effects of a predicted shift from Norway spruce to European beech in southwest Germany. They show that the suitable area for Norway spruce should decrease between 21 and $93 \%$, depending on the 
climatic scenario, corresponding to a decrease in the land expectation value (LEV) between $€ 690$ million and $€ 3.1$ billion. Brunette et al. (2014) used the framework of cost-benefit analysis to assess the economic rationale for converting Norway spruce stands to Douglas fir in the Montagne Noire region in central southern France. They show that the species shift is LEV-maximizing under a wide range of a priori (subjective) probabilities attached to the high mortality of Norway spruce under climate change. Second, Yousefpour et al. (2010) and Yousefpour and Hanewinkel (2014) focused on mixed stands rather than monoculture as a possible adaptation strategy. In particular, they deal with the introduction of beech into a pure Norway spruce stand. In the same vein, Schou et al. (2012) analyzed the simultaneous transformation of adjacent evenaged stands (a forest division) into mixed conifer/ broadleaved stands. Recently, Jönsson et al. (2015) compared several adaptation options to face storm risk in forests from an economic point of view and concluded that a portfolio of adaptation strategies is needed to reduce the risk of storm damage and to fulfill a variety of management goals. This short literature review reveals that, to our knowledge, no study has yet been conducted in a context of adaptation to the risk of dieback induced by a drought event, and that the reduction of rotation length is never analyzed from an economic perspective as a potential adaptation strategy.

In this paper, our objective is to address the reduction of rotation length to deal with the risk of drought-induced decline events taking a multidisciplinary approach. We first estimate probabilities and impacts of drought events using both water balance modeling and knowledge of tree vulnerability to soil water deficit, and then, using a forest economics approach, we evaluate the relevancy of reducing rotation length. We focus on a plantation of Douglas fir stand with a rotation of 55 years. The stand is located in the Burgundy (Bourgogne) region of France, the second region of Douglas fir production in France that was severely impacted by the extreme drought event in 2003. We question the economic relevance of reducing the rotation length to 40 years as a strategy to reduce the risk of drought-induced dieback. In France at this time, Douglas fir silviculture consists in rotations of around 50 years. However, Douglas fir is known to be sensitive to soil water deficit, leading to growth reduction and transpiration limitation through stomatal closure (Aussenac et al. 1984; Aussenac and Granier 1988) and changes in tree ring carbon isotope composition (Lévesque et al. 2013). Both water and nutrient availability are known to control Douglas fir productivity in its natural range (Nigh 2006; Littell et al. 2008; Chen et al. 2010). Although Douglas fir is considered to be droughttolerant compared to spruce (Lévesque et al. 2013; Vitali et al. 2017), in the event of recurrent and/or severe drought events, Douglas fir decline has been reported in France, including cases of tree mortality (Sergent et al. 2012), which are a serious concern for forest owners. In a context of climate change, leading to an increased probability of extreme drought events, including in France (Najac et al. 2010), the risk for a forest stand to experience a drought event that will induce decline is also increased. The option, consisting in the reduction of rotation length, has been recommended as a way to increase the probability of being able to cope with the drought-induced risk of decline. We explore here the economics of moving Douglas fir rotation from 55 to 40 years in a context of increasing drought occurrence due to climate change. We introduce climatic risk with a soil water balance projection using a climatic scenario, where increasing drought occurrence differs among temporal horizons (near or distant future) and depends on site fertility (low or high). We compare, from an economic point of view, three different adaptation strategies: absence of adaptation, immediate adaptation, and delayed adaptation. We also look at the sensitivity of the result to discount rates and uncertainty sources. Beyond the specificities of the case study, this paper proposes a multidisciplinary approach to address adaptation strategies.

\section{Materials and methods}

We describe our procedure step-by-step. We first present the economic method that we chose (Sect. 2.1), we then describe the case study (Sect. 2.2) and, finally, we define the variables of our study, the risk, adaptation strategies, and fertilization cost (Sect. 2.3).

\subsection{Economic method}

We follow the economic method in two steps proposed in Brunette et al. (2014). The first step consists in the calculation of the net present value (NPV) of costs and benefits for one rotation. The NPV is the present value of positive payments minus the present value of negative payments made at different points in time (Klemperer 1996). The calculation is as follows:

$\mathrm{NPV}=\sum_{i=0}^{n} \frac{B_{i}-C_{i}}{(1+r)^{i}}$

where $i$ is the year with $0 \leq i \leq n, B$ is the benefits, $C$ the costs, $r$ the discount rate, and $n$ the rotation length.

In a second step, we compute the land expectation value (LEV) as follows:

$\mathrm{LEV}=\sum_{i=0}^{\infty} \frac{B_{i}-C_{i}}{(1+r)^{i}}$

where $i$ is the year with $0 \leq i \leq n, B$ is the benefits, $C$ the costs, $r$ the discount rate, and $n$ the rotation length. The private forest owner's objective is assumed to maximize the LEV. This criterion is well suited to our analysis because the infinite 
Table 1 Silvicultural operations and associated benefits as a function of rotation length

Operations (year) Benefits for long rotation (LR) in $€ /$ ha Benefits for short rotation (SR) in $€ /$ ha Harvested (stems/ha) Harvested volume in $\mathrm{m}^{3} / \mathrm{ha}$

\begin{tabular}{|c|c|c|c|c|}
\hline Initial costs & -1915 & -1915 & & \\
\hline Maintenance (1) & -150 & -350 & & \\
\hline Maintenance (2) & -200 & -200 & & \\
\hline Maintenance (3) & -150 & & & \\
\hline Maintenance (4) & & -200 & & \\
\hline Maintenance (5) & -200 & & & \\
\hline Maintenance (16) & -700 & & & \\
\hline Thinning (20) & & 2318 & 508 & 92 \\
\hline Thinning (22) & 1344 & & 385 & 70 \\
\hline Thinning (25) & & 1676 & 150 & 57 \\
\hline Thinning (29) & 1950 & & 180 & 67 \\
\hline Thinning (30) & & 2277 & 100 & 59 \\
\hline Harvest (40) & & 29,878 & 342 & 503 \\
\hline Thinning (42) & 7179 & & 190 & 143 \\
\hline Thinning (48) & 5058 & & 70 & 90 \\
\hline Harvest (55) & 38,372 & & 275 & 612 \\
\hline $\mathrm{NPV}^{\mathrm{a}}$ & $\mathrm{NPV}_{\mathrm{LR}}=16,873$ & $\mathrm{NPV}_{\mathrm{SR}}=14,735$ & & \\
\hline
\end{tabular}

Source: Institute for Forest Development (IDF) and the Société Forestière de la Caisse des Dépôts et Consignations (SFCDC)

a Author's calculations

discounting makes it possible to compare management options associated with different temporal horizons (Morel and Terreaux 1995), such as Douglas fir with rotations of 55 years and 40 years.

Such an economic criterion assumes that the silvicultural path is identical for each rotation. This means that each operation (thinning, maintenance, harvest) is implemented at the same date and for the same cost/benefit, during an infinite period. Consequently, if the stand suffers from a drought, it is assumed that the forest manager will follow the silvicultural path up to the final harvest. This criterion is largely used in the forest economics literature (Yousefpour et al. 2012), and current researches try to extend it when future parameters are uncertain (Amacher et al. 2011), offering thus interesting tools for future research.

\subsection{Case study}

The silvicultural path, presented in Table 1, represents the costs and benefits associated with technical operations on the Douglas fir stand depending on the rotation length, 55 years or 40 years. $^{2}$ These two rotation lengths were not the result of an optimization. They were chosen after discussion with forestry experts in private forest management. They represent two realistic situations in terms of planting Douglas

\footnotetext{
${ }^{2}$ We assume that the quality of the site is identical for the two management options, rotation length of 40 years and 55 years, mainly because the two options that we compare involve the same tree species in the same region.
}

fir in the Burgundy region and, as a consequence, the experts can provide us the data presented in Table 1. We consider that the Douglas fir stand is composed of 1100 stems/ha without natural regeneration. Planting costs $€ 1915 / \mathrm{ha}$, regardless of the rotation length. The difference concerns the number of operations on the stand, their objective (maintenance, thinning, harvest), and the type of wood products to be sold.

The choice of a discount rate is a debate in forest economics for a long time (Forston 1986; Klemperer et al. 1994, etc.) and nothing seems to be decided. Indeed, following Brukas et al. (2001) the usual range for forestry project is [2\%, 4\%], following Calvet et al. (1997) it may be higher for short rotation period, and it should be $4 \%$ following Snowdon and Harou (2014). After discussion with the forestry experts, we assume a $2 \%$ discount rate, and to analyze the robustness of our results to the variation of this parameter, we perform a sensitivity analysis (see Sect. 3.2).

These silvicultural data are constructed following the same price curve. The prices go from $20 € / \mathrm{m}^{3}$ for Douglas fir of around 20 years old to more than $60 € / \mathrm{m}^{3}$ for Douglas fir of 55 years old. For instance, for the short rotation, the first thinning occurs at 20 years and $92 \mathrm{~m}^{3} /$ ha are harvested, representing $508 \mathrm{stems} / \mathrm{ha}$. The timber price is $€ 25.2 / \mathrm{m}^{3}$, so that $25.2 \times 92=€ 2318 / \mathrm{ha}$. In the same way, for the long rotation, the harvest occurs at 55 years and $612 \mathrm{~m}^{3} /$ ha are harvested, representing $275 \mathrm{stems} / \mathrm{ha}$. The price is $€ 62.7 / \mathrm{m}^{3}$, so that $62.7 \times 612=€ 38,372 /$ ha.

The NPV calculated in Table 1 indicated that without risk, it is better for the forest owner, from a purely economic 
perspective, to implement a long rotation length rather than a short one.

\subsection{Variables}

In this section, we characterize the drought event in terms of frequency and intensity. We describe the adaptation options considered and we justify the introduction of a fertilization cost.

\subsubsection{Characterization of the drought event}

We consider an even-aged monoculture Douglas fir stand that has just been clear-cut and in which natural regeneration is not present. The only source of risk that we consider is the risk of drought-induced decline leading to growth reduction and to the mortality of some trees. This impact of drought occurrence evaluation requires a two-step approach:

(1) The soil water deficit is quantified using a daily water balance model (Biljou(C) Granier et al. 1999) based on current and future climates for a reference weather station (Dijon (Burgundy); source: INRA, altitude: $211 \mathrm{~m}$, rainfall: $663 \mathrm{~mm}$, mean temperature: $10.2^{\circ} \mathrm{C}$ ). The future climate for the study case resulted from the ARPEGE climate model (version 4) developed by Météo France, associated with the A1B greenhouse gas emissions scenario of the IPCC. This scenario corresponds to an increase in the average temperature in France of around + $2{ }^{\circ} \mathrm{C}$ at horizon 2050 and around $+3.2{ }^{\circ} \mathrm{C}$ at horizon 2100 , compared to the period 1970-2000. In terms of rainfall, this scenario forecasts a decrease of around $25 \mathrm{~mm} /$ year for the end of century (Brisson and Levrault 2011).

According to the CLIMATOR modeling protocol (ANR006-VULN-007; Bréda et al. 2011), the soil water balance is calculated for a Douglas fir stand with a leaf area index of 6 and two types of soil properties, in order to test the interaction between climate change and the buffering effect of soil retention properties. The Biljou(C) water balance model is run for two types of soil that differ by their soil extractable water (EW), a high one corresponding to good site fertility (EW of $127 \mathrm{~mm}$ ) and a low one corresponding to poorer site fertility (EW of $97 \mathrm{~mm}$ ).

(2) Within the framework of the DRYADE project (ANR006-VULN-004), Douglas fir dieback was shown to be drought-induced, had radial growth and a crown condition that was impaired above a drought index threshold calculated by soil water balance as described above (Sergent et al. 2012). In the present work, the probabilities of drought-induced risk of decline under future climate are calculated as the probability that the soil water deficit exceeds the intensity determined during the Douglas fir decline in Burgundy after the successive dry years from 2003 to 2006 . The probabilities are calculated for one climate model, three time slices - "recent past" or baseline (1970-2000), near future (2020-2059), and distant future (2070-2100) - and three methods of climatic data downscaling (anomalies, weather type, dynamic quantile-quantile). The interested reader can find more details concerning the climate models and the level of disintegration in the Green Book of the CLIMATOR project coordinated by Brisson and Levrault (2011).

We observed that probabilities are very dependent on methods of global to regional climate downscaling, which represent a major part of the climatic uncertainty. Indeed, Bréda et al. (2011) previously established that at regional scale where adaptation takes place, the downscaling uncertainty is far greater than the SRES hypothesis or the climate model choice. To take the uncertainties due to climatic data downscaling at the regional scale into account, we considered higher and lower probabilities for each time slice and for each soil extractable water, so that probabilities of drought-induced risk of decline range as follows (Table 2):

Probability $p_{h}$ is the highest probability (depending on downscaling method combinations) that a drought likely to induce Douglas fir decline will occur before 2059, and $a_{h}$ is the corresponding one for the 2100 horizon. In the same way, $p_{l}$ corresponds to the lowest probability that such a drought event will occur before 2059, and $a_{l}$ before 2100 . Finally, the probabilities $p$ are calculated with observed climatic data (1970-2000); i.e., they reflect the previously established probability of drought capable of inducing a decline in the studied region. These values ensure that the probability of drought occurrence will be severely increased under climate change.

Regarding the impacts of drought events on Douglas fir, we assume that either there is a drought occurrence during the next rotation (with probability $p$ ) or during all the subsequent rotations (with probability $a$ ), or that there is not (with $1-p, 1$ $-a$, respectively). If the drought does not occur, the silvicultural data are those presented in Table 1. The impact of drought on forest stands is difficult to estimate, even if some information may be extracted from scientific knowledge to characterize this impact. First, the French Forest Health Service (Département de Santé des Forêts (DSF)) did not report any Douglas fir decline due to drought events on young trees, i.e., less than 20 years old. Consequently, we assume that when the drought episode impacts Douglas fir stands, it is after the first thinning that occurs when trees are about 20 years old, regardless of the rotation length. Such an assumption is also consistent from an economic perspective because the first thinning corresponds to the first benefits. Second, after the extreme drought event of 2003 in Burgundy, it was observed 
Table 2 Probability of drought occurrence for high- and lowfertility sites

\begin{tabular}{llllll}
\hline Horizon & High-fertility site & & & Low-fertility site & \\
\cline { 2 - 3 } & Higher probability & Lower probability & & Higher probability & Lower probability \\
\hline $1970-2000$ & $p=0.41$ & $p=0.32$ & $p=0.51$ & $p=0.35$ \\
$2020-2059$ & $\mathrm{p}_{\mathrm{h}}=0.79$ & $\mathrm{p}_{\mathrm{l}}=0.44$ & & $\mathrm{p}_{\mathrm{h}}=0.83$ & $\mathrm{p}_{\mathrm{l}}=0.48$ \\
$2070-2100$ & $\mathrm{a}_{\mathrm{h}}=0.93$ & $\mathrm{a}_{\mathrm{l}}=0.68$ & & $\mathrm{a}_{\mathrm{h}}=0.93$ & $\mathrm{a}_{\mathrm{l}}=0.71$ \\
\hline
\end{tabular}

Source: Authors' calculations

that the loss of volume (including increment loss and volume of dead trees) varied between 15 and $40 \%$, depending on the stand (Sergent et al. 2012), so that we assume a loss of $15 \%$. To sum up, we assume that with a drought occurrence at each thinning (except the first one) or at final harvest, the volume and, thus, the associated benefits are $15 \%$ lower than without a drought occurrence (see Table 1). For example, for the long rotation, if the drought occurs, as assumed after the first thinning, the harvested volume at the second thinning (year 29) is reduced by $15 \%$, going from $67 \mathrm{~m}^{3}$ without a drought event to $57 \mathrm{~m}^{3}$ with a drought event and, consequently, the associated benefits are also reduced by $15 \%$, dropping from $€ 1950 /$ ha to $€ 1657 /$ ha.

In this context, the NPVs change as follows: $\mathrm{NPV}_{\mathrm{DR}}$ $(\mathrm{LR})=€ 14,009 / \mathrm{ha}$ and $\mathrm{NPV}_{\mathrm{DR}}(\mathrm{SR})=€ 12,364 / \mathrm{ha}$. Note that the impact of a drought occurrence on the NPV is not proportional. Indeed, while the timber volumes and benefits are reduced by $15 \%$ due to drought occurrence, the NPVs for short rotations are reduced by $19 \%$ (from $€ 14,735 /$ ha without drought to $€ 12,364 /$ ha with drought) and for long rotations by $20 \%$ (from $€ 16,873 /$ ha without drought to $€ 14,009$ /ha with drought). Therefore, the percentage impact of drought on the NPV seems to be similar regardless of the rotation length.

\subsubsection{Adaptation strategies}

To face the risk of drought-induced decline, as defined in the previous section, we consider that the owner may react in three different manners:

- Strategy 1 (S1): replanting Douglas fir now with a rotation of 55 years and keeping this management option for subsequent rotations (no adaptation, silviculture as usual).
- Strategy 2 (S2): planting Douglas fir now with a rotation of 40 years and keeping this management option for subsequent rotations (immediate adaptation).

- Strategy 3 (S3): replanting Douglas fir now with a rotation of 55 years with the intention of shifting to shorter rotations of 40 years after the end of the rotation (delayed adaptation).

Natural regeneration is not considered as an option for adaptation for any of these strategies. We make the assumption that Douglas fir stands are only renewed by planting.

The objective of the present study is to economically compare these three adaptation strategies, with Strategy 1 as a benchmark. For that purpose, we will compute the LEV associated with each strategy.

\subsubsection{Fertilization cost}

Let us now introduce a fertilization cost (FC). Indeed, the reduction of rotation increases the exportation of young wood with a higher nutrient content, and then reduces the soil fertility that could impair the sustainability of productivity and profitability, especially in the case of low site fertility (Ranger and Turpault 1999; Sergent et al. 2012). Recent results in biogeochemical cycling in forests recommended compensating such nutrient exportation in sites with poor fertility by liming or fertilization in order to sustain long-term productivity. To take this recommendation to sustain stand productivity into account, we introduce a fertilization cost of $€ 250 /$ ha for each new planting (i.e., every 40 years) on the low soil extractable water and low fertility. We consider that in the case of high site fertility, this extra cost is not necessary.

Consequently, in the case of high site fertility, the LEVs are

$$
\begin{aligned}
L E V(S 1)= & p\left(N P V_{D R}(L R)+\left[a\left(\frac{N P V_{D R}(L R)}{(1+r)^{55}} \times \frac{(1+r)^{55}}{(1+r)^{55}-1}\right)+(1-a)\left(\frac{N P V(L R)}{(1+r)^{55}} \times \frac{(1+r)^{55}}{(1+r)^{55}-1}\right)\right]\right) \\
& +(1-p)\left(N P V(L R)+\left[a\left(\frac{N P V_{D R}(L R)}{(1+r)^{55}} \times \frac{(1+r)^{55}}{(1+r)^{55}-1}\right)+(1-a)\left(\frac{N P V(L R)}{(1+r)^{55}} \times \frac{(1+r)^{55}}{(1+r)^{55}-1}\right)\right]\right)
\end{aligned}
$$




$$
\begin{aligned}
\operatorname{LEV}(S 2)= & p\left(N P V_{D R}(S R)+\left[a\left(\frac{N P V_{D R}(S R)}{(1+r)^{40}} \times \frac{(1+r)^{40}}{(1+r)^{40}-1}\right)+(1-a)\left(\frac{N P V(S R)}{(1+r)^{40}} \times \frac{(1+r)^{40}}{(1+r)^{40}-1}\right)\right]\right) \\
& +(1-p)\left(N P V(S R)+\left[a\left(\frac{N P V_{D R}(S R)}{(1+r)^{40}} \times \frac{(1+r)^{40}}{(1+r)^{40}-1}\right)+(1-a)\left(\frac{N P V(S R)}{(1+r)^{40}} \times \frac{(1+r)^{40}}{(1+r)^{40}-1}\right)\right]\right)
\end{aligned}
$$

$L E V(S 3)=p\left(N P V_{D R}(L R)+\frac{L E V(S 2)}{(1+r)^{55}}\right)+(1-p)\left(N P V(L R)+\frac{L E V(S 2)}{(1+r)^{55}}\right)$

Note that we choose to present the non-simplified equations in order to make salient the different possible states of nature. A simplified version of Eq. (1) will give

$$
\begin{aligned}
L E V(S 1)= & N P V_{D R}(L R)\left(p+\frac{a}{(1+r)^{55}-1}\right) \\
& +N P V(L R)\left((1-p)+\frac{(1-a)}{(1+r)^{55}-1}\right)
\end{aligned}
$$

In the case of low site fertility, the LEV of Strategy 1 does not change due to independence with short rotation, but the LEVs of Strategies 2 and 3 become

$$
\begin{aligned}
L E V_{F C}(S 2)= & p\left(N P V_{D R}(S R)+\left[a\left(\frac{N P V_{D R}(S R)-F C}{(1+r)^{40}} \times \frac{(1+r)^{40}}{(1+r)^{40}-1}\right)+(1-a)\left(\frac{N P V(S R)-F C}{(1+r)^{40}} \times \frac{(1+r)^{40}}{(1+r)^{40}-1}\right)\right]\right) \\
& +(1-p)\left(N P V(S R)+\left[a\left(\frac{N P V_{D R}(S R)-F C}{(1+r)^{40}} \times \frac{(1+\mathrm{r})^{40}}{(1+r)^{40}-1}\right)+(1-a)\left(\frac{N P V(S R)-F C}{(1+r)^{40}} \times \frac{(1+r)^{40}}{(1+r)^{40}-1}\right)\right]\right)
\end{aligned}
$$

$$
\begin{aligned}
L E V_{F C}(S 3)= & p\left(N P V_{D R}(L R)+\frac{L E V_{F C}(S 2)}{(1+r)^{55}}\right) \\
& +(1-p)\left(N P V(L R)+\frac{L E V_{F C}(S 2)}{(1+r)^{55}}\right)
\end{aligned}
$$

\section{Results}

Table 3 presents the LEV of each strategy as a function of the site fertility (high or low) and the probability of risk occurrence (high or low). The $\operatorname{LEV}(\mathrm{S} 1)$ is obtained from Eq. (1), the LEV(S2) from Eq. (2) for high fertility and Eq. (4) for low fertility, and the LEV(S3) from Eq. (3) for high fertility and Eq. (5) for low fertility.
Table 3 reveals that Strategy 2 provides the best economic return compared to the two other ones in all scenarios. As a result, from an economic point of view, Strategy 2 dominates Strategy 3, which dominates Strategy 1 . Note that the absence of adaptation is the worst option from an economic perspective.

We analyze the sensitivity of this result to the level of loss (Sect. 3.1) and the discount rate (Sect. 3.2). Our approach also makes it possible to observe the effect of the uncertainty sources on the LEV (Sect. 3.3).

\subsection{Sensitivity to the level of loss}

The results presented in Table 3 are true for a loss of volume of $15 \%$ in the case of drought occurrence. However, as indicated 
Table 3 LEV for each strategy as a function of the site fertility, the probability of risk occurrence, and for a $15 \%$ loss of timber volume $(€ /$ ha)

\begin{tabular}{llllll}
\hline & \multicolumn{3}{l}{ High fertility } & & \multicolumn{2}{l}{ Low fertility } \\
\cline { 2 - 3 } \cline { 5 - 6 } & $\mathrm{p}_{\mathrm{h}}, \mathrm{a}_{\mathrm{h}}$ & $\mathrm{p}_{\mathrm{l}}, \mathrm{a}_{\mathrm{l}}$ & & $\mathrm{p}_{\mathrm{h}}, \mathrm{a}_{\mathrm{h}}$ & $\mathrm{p}_{\mathrm{l}}, \mathrm{a}_{\mathrm{l}}$ \\
\hline LEV(S1) & 21,818 & 23,183 & & 21,703 & 23,025 \\
LEV(S2) & 23,234 & 24,555 & & 22,932 & 24,194 \\
LEV(S3) & 22,429 & 23,876 & & 22,213 & 23,640 \\
\hline
\end{tabular}

Source: Authors' calculations

before, a loss of volume ranging from 15 to $40 \%$, depending on the stand, was observed after the drought of 2003 in Burgundy (Sergent et al. 2012), so that the question is: are these results still true for a loss of volume of $40 \%$ ? And the answer is yes, as indicated in Table 4.

However, for higher levels of loss that may be envisaged in the future due to climate change effects, the results change. More precisely, we can observe a cross-effect of the level of loss in the case of drought occurrence and the level of probability of the occurrence of the drought event. Indeed, we observed that since the loss of volume reached $48 \%$, Strategy 3 dominates the two other ones when the probabilities are low. This means that a trade-off appears between the frequency and the intensity of the damage. Thus, if the potential damage is high (>48\%) but the probabilities of occurrence of this potential damage are low, then the best economic option is to delay adaptation (Strategy 3), regardless of the fertility level. On the contrary, if the potential damage is "low" $(<48 \%)$ but the probabilities of occurrence are high, then it seems better, from an economic point of view, to adopt an immediate adaptation (Strategy 2), regardless of the fertility level. Note that in the studied condition with such a severe increase of drought events and the associated risk of decline, adaptation is always preferable to the absence of adaptation, but the timing of this adaptation may change as a function of the level of loss.

\subsection{Sensitivity to the discount rate}

It is rather complex to adopt a discount rate for forest projects (Calvet et al. 1997; Gosselin et al. 2011), so we conducted a

Table 4 LEV for each strategy as a function of the site fertility, the probability of risk occurrence, and for a $40 \%$ loss of timber volume $(€ / \mathrm{ha})$

\begin{tabular}{|c|c|c|c|c|}
\hline & \multicolumn{2}{|c|}{ High fertility } & \multicolumn{2}{|c|}{ Low fertility } \\
\hline & $\mathrm{p}_{\mathrm{h}}, \mathrm{a}_{\mathrm{h}}$ & $\mathrm{p}_{1}, \mathrm{a}_{1}$ & $\mathrm{p}_{\mathrm{h}}, \mathrm{a}_{\mathrm{h}}$ & $\mathrm{p}_{1}, \mathrm{a}_{1}$ \\
\hline $\mathrm{LEV}(\mathrm{S} 1)$ & 15,796 & 19,437 & 15,491 & 19,015 \\
\hline $\mathrm{LEV}(\mathrm{S} 2)$ & 17,068 & 20,591 & 16,609 & 19,974 \\
\hline LEV(S3) & 16,584 & 20,442 & 16,124 & 19,929 \\
\hline
\end{tabular}

Source: Authors' calculations sensitivity analysis on the $2 \%$ discount rate. Figure 1 represents the variation of the LEV function of the discount rate for high-fertility and high-probability scenarios.

The result is interesting since it challenges the domination of Strategy 2 that we obtain (except when the volume of loss is higher than $48 \%$ and probabilities are low). Indeed, we can observe that when the discount rate is $1 \%$, we have $\mathrm{LEV}(\mathrm{S} 1)>\operatorname{LEV}(\mathrm{S} 3)>\operatorname{LEV}(\mathrm{S} 2)$. Since the discount rate increases, we then obtain our common result $\operatorname{LEV}(\mathrm{S} 2)>$ $\operatorname{LEV}(\mathrm{S} 3)>\operatorname{LEV}(\mathrm{S} 1)$. A forest owner with a low rate of preference for the present (i.e., low discount rate) is attracted by the high return from final harvest when the rotation length is long, and thus prefers Strategy 1 that maintains a long rotation. In keeping with this idea, his/her worst option is the immediate adaptation of Strategy 2. Strategy 3 is thus an intermediate strategy. When the rate of preference increases, the forest owner over-estimates the expenses linked to maintenance operations when the rotation length is long and appreciates the fact that benefits occur earlier in time (year 20) when the rotation length is shorter, thus preferring Strategy 2.

This result is true regardless of the fertility level and the level of probabilities.

\subsection{Sensitivity to the uncertainty sources}

Our approach makes it possible to quantify the respective contribution of the uncertainty on the downscaled future climate, the adaptation strategy, and the site fertility to the economic criterion, the LEV.

We show that the LEV is first sensitive to climatic uncertainty. This means that for the same adaptation strategy and the same site fertility, a gap is observed between the LEV calculated with high probabilities $\left(p_{h}, a_{h}\right)$ and low probabilities $\left(p_{l}, a_{l}\right)$. For example, consider Strategy 1 and a high fertility, then the LEV associated with low probabilities is $€ 21,818 / \mathrm{ha}$, and with high probabilities, it is $€ 23,183 /$ ha, i.e., a difference of $6.25 \%$.

The economic criterion is also sensitive to the adaptation strategy. Indeed, differences appeared between the LEV function of the adaptation strategy. Consequently, for the same fertility and the same level of probabilities (high or low), we note a gap between the LEV of the different strategies. For example, consider a high fertility and high probabilities $\left(p_{h}, a_{h}\right)$. If we compare Strategies 1 and 2, we observe that $\operatorname{LEV}(\mathrm{S} 1)=€ 21,818 /$ ha and that $\operatorname{LEV}(\mathrm{S} 2)=€ 23,234 /$ ha, i.e., a difference of $6.49 \%$. Note that the difference between $\mathrm{LEV}(\mathrm{S} 1)$ and $\mathrm{LEV}(\mathrm{S} 2)$ is approximately $6 \%$ regardless of the fertility level and the probabilities (high or low). The difference between $\operatorname{LEV}(\mathrm{S} 1)$ and $\operatorname{LEV}(\mathrm{S} 2)$ is then $5.92 \%$ for high fertility and low probabilities, $5.08 \%$ for low fertility and low probabilities, and $5.66 \%$ for low fertility and high probabilities.

The third sensitivity concerns site fertility. The increase in drought occurrence in the studied region is such that the soil 
Fig. 1 Evolution of the LEV of each adaptation strategy (S1, S2, and $\mathrm{S} 3$ ) as a function of the value of the discount rate for the scenario with high fertility and high probability

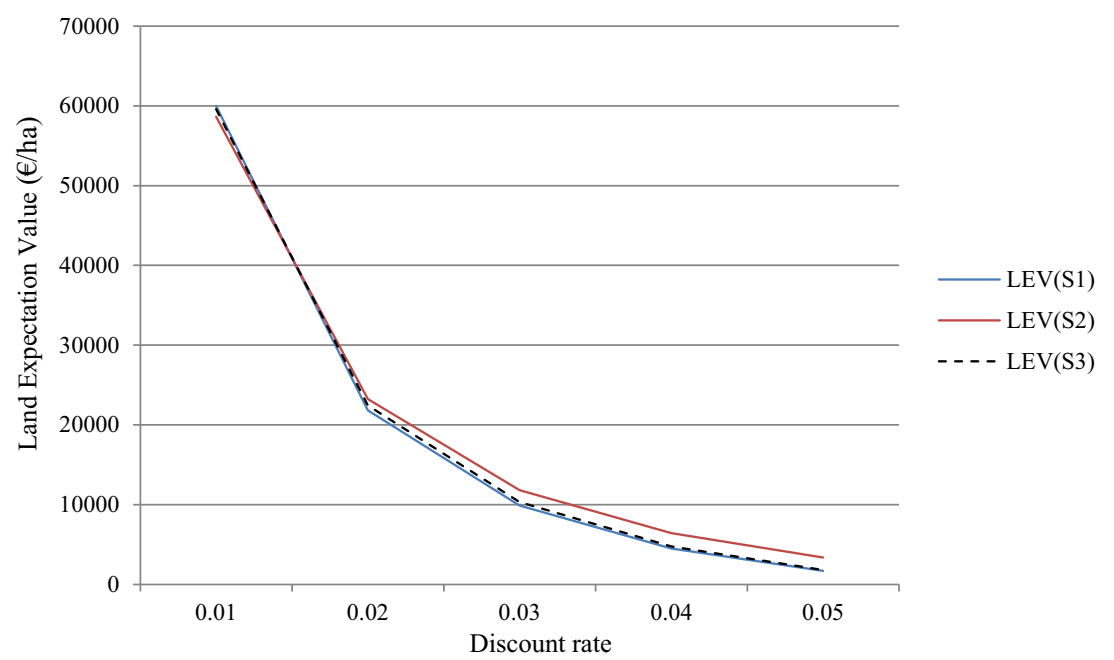

extractable water cannot significantly mitigate the risk of decline: the LEV is thus insensitive to site fertility. Consequently, for the same adaptation strategy and the same level of probabilities (high or low), the gap between the LEV obtained with high fertility and low fertility is very low, generally less than $1 \%$. For instance, for Strategy 1 and high probabilities $\left(p_{h}, a_{h}\right)$, the LEV for high fertility is €21,818/ha and the one for low fertility is $€ 21,703 /$ ha, i.e., a difference of $0.53 \%$.

To sum up, climatic uncertainty at the regional scale is passed on to biophysical impact models and then to economic models, thus creating a cascade effect in the adaptation decision-making process.

\section{Discussion}

Our results suggest that reducing the rotation length is economically profitable for the forest owner, rather than the absence of adaptation.

This result is obtained without considering forest owner's preferences towards risk and time, while the literature shows that these parameters may play a significant role on some forest management decisions (Uusivuori 2002; Alvarez and Koskela 2006; Couture and Reynaud 2008; Brunette et al. 2017).

In addition, this conclusion is true for a $2 \%$ discount rate, and the sensitivity analysis conducted on this unpredictable parameter in the future highlights the role of the discount rate in such an analysis, as reported by other authors (Calvet et al. 1997; Gosselin et al. 2011; Brunette et al. 2014).

Moreover, our study focuses on financial loss, neglecting other losses like non-timber ones. Indeed, the loss associated with the occurrence of a drought event is expressed in terms of timber volume and converted to financial loss through timber prices. Consequently, there is no consideration of non-timber losses like the decrease of the carbon stock, deterioration of habitats, and lower biodiversity. This remark is linked to the paper of Englin et al. (2000). Their results indicate that while fire risk shortens the rotation period, the consideration of nonmarket values associated with wilderness recreation would lengthen the rotation periods. In the same vein, we do not consider some major expenses for the owners such as the initial purchase of the forest stand (or of the ground), the land tax, potential insurance premiums (civil liability, natural risks), and costs linked to overseeing or management (expert, cooperative). Consequently, the land expectation value that we calculated could be overestimated.

In addition, if adaptation is preferable to the absence of adaptation, as suggested by our result, we can wonder why forest owners may be reluctant to implement adaptation options. The answer is probably linked to the forest owner's risk perception. Indeed, to implement adaptation strategies, forest owners have to be convinced that climate change may be a threat to their forests (Sousa-Silva et al. 2016). Some papers highlight the fact that forest owners' risk perception is a major issue when dealing with adaptation strategies (Blennow and Persson 2009; Blennow et al. 2012; Yousefpour and Hanewinkel 2015). For example, Yousefpour and Hanewinkel (2015) focused on forestry professionals' perceptions of climate change, impacts, and adaptation strategies for forests in south-west Germany. The majority of respondents said they were under-informed about climate change, even if most of them considered climate change as a reality.

Finally, we focused on a case study, a Douglas fir stand facing an increasing risk of drought-induced decline attributable to climate change, so that further research is needed to generalize our conclusions at the national scale and to test other adaptation options like natural regeneration instead of planting, lowering the stand leaf area index for a more "water-saving" silviculture, or rotations shorter than 40 years. Nevertheless, the present study offers an interesting initial approach. 


\section{Conclusion}

This paper analyses the reduction of rotation from 55 to 40 years in the context of a Douglas fir stand as an option to cope with the increasing risk of tree decline induced by recurrent drought events due to a decrease in both exposure and tree vulnerability due to age. From a forest management point of view, this is a winwin strategy. Our results indicate that from an economic point of view, it is still true. Indeed, we show that immediate reduction of rotation length seems to be the best economic option for the forest owner, followed by a delayed adaptation and, finally, the absence of adaptation. Consequently, the reduction of rotation length seems to be an efficient strategy to cope with the drought-induced risk of decline, as it was to cope with the risk of forest fires and storms (Reed 1984; Martell 1994; Haight et al. 1995; Amacher et al. 2005; Kuuluvainen and Tahvonen 1999; Englin et al. 2000; Price 2011; Rakotoarison and Loisel 2017). We demonstrate the sensitivity of this result to the severity of timber loss in the case of a drought event occurrence. If the loss of timber volume is higher than $48 \%$, then delayed adaptation may be preferable if the probabilities of drought occurrence are low. On the other hand, if the loss is lower than $48 \%$ and the probabilities are high, then immediate adaptation seems to be relevant. We also prove the sensitivity of the result to the discount rate.

The multidisciplinary approach developed here makes it possible to quantify biological impacts of future drought events and to economically evaluate several adaptation strategies to cope with the risk of decline. Such an approach requires close collaboration between economists specialized in risks and the community of climatologists and ecologists who study the biological impacts of climate change. As indicated by Yousefpour et al. (2012), "Future studies should attempt to bridge the gap between comprehensive ecological models and economic models to assist forest decision makers [...]."

Acknowledgments We thank Abdoulaye Sacko for the work performed during the training course of Master's degree at the Laboratory of Forest Economics. We also thank Jean-Luc Peyron for his helpful comments.

Funding The project was funded by the Mixed Technological Network for the Adaptation of Forest to Climatic Change (RMT AFORCE; http:// www.reseau-aforce.fr/). The UMRs BETA and Forest Ecology and Ecophysiology are supported by a grant overseen by the French National Research Agency (ANR) as part of the "Investissements d'Avenir" program (ANR-11-LABX-0002-01; Lab of Excellence ARBRE).

Data availability The datasets generated during and/or analyzed during the current study are available from the corresponding author on reasonable request

\section{Compliance with ethical standards}

Conflicts of interest The authors declare that they have no conflict of interest.

\section{References}

Alvarez LHR (2004) Stochastic forest stand value and timber harvesting. SIAM J Control Optim 42:1972-1993. https://doi.org/10.1137/ S0363012901393456

Alvarez LHR, Koskela E (2003) On forest rotation under interest rate variability. Int Tax Public Financ 10(4):489-503. https://doi.org/ 10.1023/A:1024695701513

Alvarez LHR, Koskela E (2005) Wicksellian theory of forest rotation under interest rate variability. J Econ Dyn Control 29(3):529-545. https://doi.org/10.1016/j.jedc.2004.03.002

Alvarez LHR, Koskela E (2006) Does risk aversion accelerates optimal forest rotation under uncertainty? J For Econ 12:171-184. https:// doi.org/10.1016/j.jfe.2006.06.001

Amacher GS, Malik AS, Haight RG (2005) Not getting burned: the importance of fire prevention in forest management. Land Econ 81(2): 284-302. https://doi.org/10.3368/le.81.2.284

Amacher GS, Brazee RJ, Deegen P (2011) Faustmann continues to yield. J For Econ 17(3):231-234. https://doi.org/10.1016/j.jfe.2011.06. 001

Archaux F, Wolters V (2006) Impact of summer drought on forest biodiversity: what do we know? Ann For Sci 63(6):645-652. https://doi. org/10.1051/forest:2006041

Aussenac G, Granier A (1988) Effects of thinning on water stress and growth in Douglas fir. Can J For Res 18:100-105. https://doi.org/10. 1139/x88-015

Aussenac G, Granier A, Ibrahim M (1984) Influence du dessèchement du sol sur le fonctionnement hydrique et la croissance du Douglas (Pseudotsuga Menziesii (Mirb.) Franco). Acta Oecol 5:241-253

Becker M, Lévy G (1988) A propos du dépérissement des forêts : climat, sylviculture et vitalité de la sapinière vosgienne. Rev For Fra 40: 345-358. https://doi.org/10.4267/2042/25902

Blennow K, Persson J (2009) Climate change: motivation for taking measure to adapt. Glob Environ Chang 19:100-104. https://doi. org/10.1016/j.gloenvcha.2008.10.003

Blennow K, Persson J, Tomé M, Hanewinkel M (2012) Climate change: believing and seeing implies adapting. PLoS One 7(11):e50182. https://doi.org/10.1371/journal.pone.0050182

Brazee RJ, Mendelsohn R (1988) Timber harvesting with fluctuating prices. For Sci 34(2):359-372. https://doi.org/10.1093/ forestscience/34.2.359

Bréda N, Badeau V (2008) Forest tree responses to extreme drought and some biotic events: towards a selection according to hazard tolerance? Compt Rendus Geosci 340:651-662. https://doi.org/10.1016/ j.crte.2008.08.003

Bréda N, Peiffer M (2014) Vulnerability to forest decline in a context of climate changes: new prospects about an old question in forest ecology. Ann For Sci 71:627-631. https://doi.org/10.1007/s13595-0140411-3

Bréda N, Granier A, Huc R, Dreyer E (2006) Temperate forest trees and stands under severe drought: a review of ecophysiological responses, adaptation processes and long-term consequences. Ann For Sci 63:625-644. https://doi.org/10.1051/forest:2006042

Bréda N, Bosc A, Badeau V (2011) Some aspects of climate change and forests in metropolitan France. In: Brisson N, Levrault F (eds) The Green book of the CLIMATOR project. Climate change, agriculture and forests in France: simulations of the impacts on the main species. ADEME, pp 225-236 
Brisson N, Levrault F (2011) Green book of the CLIMATOR project. Climate change, agriculture and forests in France: simulations of the impacts on the main species. ADEME Editions, March 2011, $334 p$

Brukas V, Jellesmark Thorsen B, Helles F, Tarp P (2001) Discount rate and harvest policy: implications for Baltic forestry. Forest Policy Econ 2:143-156. https://doi.org/10.1016/S1389-341(01)00050-8

Brunette M, Costa S, Lecocq F (2014) Economics of species change subject to risk of climate change and increasing information: a (quasi-)option value analysis. Ann For Sci 71(2):279-290. https://doi. org/10.1007/s13595-013-0281-0

Brunette M, Foncel J, Kéré E (2017) Attitude towards risk and production decision: an empirical analysis on French private forest owners. Environ Model Assess 22(6):563-576. https://doi.org/10.1007/ s10666-017-9570-6

Calvet P, Lemoine B, Peyron JL (1997) Taux d'actualisation et conduite sylvicole des peuplements forestiers: un exemple dans le cas du pin maritime en France. Can J For Res 27:1268-1275. https://doi.org/ $10.1139 / \times 97-073$

Chang FR (2005) On the elasticities of harvesting rules. J Econ Dyn Control 29:469-485. https://doi.org/10.1016/j.jedc.2004.02.003

Chen PY, Welsh C, Hamann A (2010) Geographic variation in growth response of Douglas fir to interannual climate variability and projected climate change. Glob Chang Biol 16:3374-3385. https:// doi.org/10.1111/j.1365-2486.2010.02166.x

Clarke HR, Reed WJ (1989) The tree-cutting problem in a stochastic environment. J Econ Dyn Control 13:569-595. https://doi.org/10. 1016/0165-1889(89)90004-3

Clarke HR, Reed WJ (1990) Harvest decisions and asset valuations for biological resources exhibiting size-dependent stochastic growth. Int Econ Rev 31:147-169. https://doi.org/10.2307/2526634

Couture S, Reynaud A (2008) Multi-stand forest management under a climatic risk: do time and risk preferences matter? Environ Model Assess 13:181-193. https://doi.org/10.1007/s10666-007-9121-7

de Kort I, Baas P (1997) Ring width patterns of Douglas-fir in relation to crown vitality and age. IAWA J 18:53-67. https://doi.org/10.1163/ 22941932-90001460

de Vries W, Dobbertin MH, Solberg S, van Dobben HF, Schaub M (2014) Impacts of acid deposition, ozone exposure and weather conditions on forest ecosystems in Europe: an overview. Plant Soil 380:1-45. https://doi.org/10.1007/s11104-014-2056-2

Englin J, Boxall P, Hauer G (2000) An empirical examination of optimal rotations in a multiple-use forest in the presence of fire risk. J Agric Resour Econ 25:14-27

Forston JC (1986) Factors affecting the discount rate for forestry investments. For Prod J 36(6):67-72

Gosselin M, Costa S, Paillet Y, Chevalier H (2011) Actualisation en forêt: pour quelles raisons et à quel taux? Rev For Fra 63:445-455. https:// doi.org/10.4267/2042/45828

Gottschalk KW (1995) Using silviculture to improve health in northeastern conifer and eastern hardwood forests. In: Eskew LG (compiler) Forest health through silviculture. U.S. Department of Agriculture Forest Service, Fort Collins, Colo. General Technical Report RM267: 219-226

Granier A, Bréda N, Biron P, Villette S (1999) A lumped water balance model to evaluate duration and intensity of drought constraints in forest stands. Ecol Model 116:269-283. https://doi.org/10.1016/ S0304-3800(98)00205-1

Haight RG, Smith WD, Straka TJ (1995) Hurricanes and the economics of loblolly pine plantations. For Sci 41:675-688. https://doi.org/10. 1093/forestscience/41.4.675

Hanewinkel M, Hummel S, Cullmann DA (2010) Modelling and economic evaluation of forest biome shifts under climate change in Southwest Germany. For Ecol Manag 259:710-719. https://doi. org/10.1016/j.foreco.2009.08.021
Insley M (2002) A real options approach to the valuation of a forestry investment. J Environ Econ Manag 44:471-492. https://doi.org/10. 1006/jeem.2001.1209

Insley MC, Rollins K (2005) On solving the multirotational timber harvesting problem with stochastic prices: a linear complementarity formulation. Am J Agric Econ 87:735-755. https://doi.org/10. $1111 / j .1467-8276.2005 .00759 . x$

IPCC (2012) Summary for policymakers. In: Field CB, Barros V, Stocker TF, Qin D, Dokken DJ, Ebi KL, Mastrandrea MD, Mach KJ, Plattner G-K, Allen SK, Tignor M, Midgley PM (eds) Managing the risks of extreme events and disasters to advance climate change adaptation. A Special Report of Working Groups I and II of the Intergovernmental Panel on Climate Change. Cambridge University Press, Cambridge and New York, pp 1-19

IPCC (2014) IPCC SREX summary for policymakers

Jönsson AM, Lagergren F, Smith B (2015) Forest management facing climate change - an ecosystem model analysis of adaptation strategies. Mitig Adapt Strateg Glob Chang 20(2):201-220. https://doi. org/10.1007/s11027-013-9487-6

Kaipainen T, Liski J, Pussinen A, Karjalainen T (2004) Managing carbon sinks by changing rotation length in European forests. Environ Sci Pol 7:205-219. https://doi.org/10.1016/j.envsci.2004.03.001

Keenan RJ (2012) Adaptation of forests and forest management to climate change: an editorial. Forests 3:75-82. https://doi.org/10.3390/ f3010075

Kennedy MC, Ford ED, Hinckley TM (2009) Defining how aging Pseudotsuga and Abies compensate for multiple stresses through multi-criteria assessment of a functional-structural model. Tree Physiol 30:3-22. https://doi.org/10.1093/treephys/tpp096

Klemperer WD (1996) Forest resource economics and finance, McGrawHill Series in Forest Resources. McGraw-Hill, NewYork, 551p

Klemperer WD, Cathcart JF, Haering T, Alig RJ (1994) Risk and the discount rate in forestry. Can J For Res 24(2):390-397. https://doi. org/10.1139/x94-052

Kolström M, Lindner M, Vilén T, Maroschek M, Seidl R, Lexer MJ, Netherer S, Kremer A, Delzon S, Barbati A, Marchetti M, Corona P (2011) Reviewing the science and implementation of climate change adaptation measures in European forestry. Forests 2:961982. https://doi.org/10.3390/f2040961

Kuuluvainen T, Tahvonen O (1999) Testing the forest rotation model: evidence from panel data. For Sci 45(4):539-551. https://doi.org/ 10.1093/forestscience/45.4.539

Lévesque M, Saurer M, Siegwolf R, Eilmann B, Brang P, Bugmann H, Rigling A (2013) Drought response of five conifer species under contrasting water availability suggests high vulnerability of Norway spruce and European larch. Glob Chang Biol 19:3184 3199. https://doi.org/10.1111/gcb.12268

Lindner M, Lasch P, Erhard M (2000) Alternative forest management strategies under climate change: prospects for gap model applications in risk analyses. Silva Fenn 34:101-111. https://doi.org/10. 14214/sf.634

Liski J, Pussinen A, Pingoud K, Mäkipää R, Karjalainen T (2001) Which rotation length is favourable for carbon sequestration? Can J For Res 31:2004-2013. https://doi.org/10.1139/x01-140

Littell JS, Peterson DL, Tjoelker M (2008) Douglas-fir growth in mountain ecosystems: water limits tree growth from stand to region. Ecol Monogr 78:349-368. https://doi.org/10.1890/07-0712.1

Martell DL (1994) The impact of fire on timber supply in Ontario. For Chron 70:164-173. https://doi.org/10.5558/tfc70164-2

McDowell N, Phillips N, Lunch C, Bond B, Ryan MG (2002) An investigation of hydraulic limitation and compensation in large old Douglas-fir trees. Tree Physiol 22:763-774

Morel M, Terreaux JP (1995) L'estimation de la valeur des forêts à travers un exemple: entre simplification abusive et complexité du réel. Rev For Fra XLVII 2:151-161. https://doi.org/10.4267/2042/26639 
Najac J, Vidal JP, Martin E, Franchisteguy L, Soubeyroux JM (2010) Changes in drought characteristics in France during the 21st century. Geophys Res Abst 12:EGU2010-8975. HAL Id: hal-00506550

Newman DH (2002) Forestry's golden rule and the development of the optimal forest rotation literature. J For Econ 8:5-27. https://doi.org/ 10.1078/1104-6899-00002

Nigh GD (2006) Impact of climate, moisture regime, and nutrient regime on the productivity of Douglas fir in coastal British Columbia, Canada. Clim Chang 76:321-337. https://doi.org/10.1007/s10584005-9041-y

Pachauri RK, Allen MR, Barros VR, Broome J, Cramer W, Christ R, Church JA, Clarke L, Dahe Q, Dasgupta P (2014) Climate change 2014: synthesis report. Contribution of Working Groups I, II and III to the fifth assessment report of the Intergovernmental Panel on Climate Change. IPCC

Price C (2011) When and to what extent do risk premia work? Cases of threat and optimal rotation. J For Econ 17:53-66. https://doi.org/10. 1016/j.jfe.2010.09.002

Rakotoarison H, Loisel P (2017) The Faustmann model under storm risk and price uncertainty: a case study of European beech in northwestern France. Forest Policy Econ 81:30-37. https://doi.org/10.1016/j. forpol.2017.04.012

Ranger J, Turpault MP (1999) Input-output nutrient budgets as a diagnostic tool for sustainable forest management. For Ecol Manag 122: 139-154. https://doi.org/10.1016/S0378-1127(99)00038-9

Reed WJ (1984) The effects of the risk of fire on the optimal rotation of forest. J Environ Econ Manag 11(3):1980-1990. https://doi.org/10. 1016/0095-0696(84)90016-0

Schou E, Jacobsen JB, Kristensen KL (2012) An economic evaluation of strategies for transforming even-aged into near-natural forestry in a conifer-dominated forest in Denmark. Forest Policy Econ 20:89-98. https://doi.org/10.1016/j.forpol.2012.02.010

Sergent AS, Bréda N, Rozenberg P (2012) Douglas-fir is vulnerable to exceptional and recurrent drought episodes and recovers less well on less fertile sites. Ann For Sci 71(6):697-708. https://doi.org/10. 1007/s13595-012-0220-5

Snowdon P, Harou P (2014) Guide to economic appraisal of forestry investments and programmes in Europe. EFI Technical Report 94, Forestry Commission

Sousa-Silva R, Ponette Q, Verheyen K, Van Herzele A, Muys B (2016) Adaptation of forest management to climate change as perceived by forest owners and managers in Belgium. For Ecosyst 3:22. https:// doi.org/10.1186/s40663-016-0082-7

Spiecker H (2003) Silvicultural management in maintaining biodiversity and resistance of forests in Europe-temperate zone. J Environ Manag 67(1):55-65. https://doi.org/10.1016/S0301-4797(02)00188-3

Spittlehouse DL, Stewart RB (2003) Adaptation to climate change in forest management. J Ecosyst Manag 4:1-11
Stollery KR (2005) Climate change and optimal rotation in a flammable forest. Nat Resour Model 18(1):91-112. https://doi.org/10.1111/j. 1939-7445.2005.tb00150.x

Thomson TA (1992) Optimal forest rotation when stumpage prices follow a diffusion process. Land Econ 68(3):329-342. https://doi.org/10. $2307 / 3146380$

Uusivuori J (2002) Non-constant risk attitudes and timber harvesting. For Sci 48:459-470. https://doi.org/10.1093/forestscience/48.3.459

Vitali V, Büntgen U, Bauhus J (2017) Silver fir and Douglas fir are more tolerant to extreme droughts than Norway spruce in south-western Germany. Glob Chang Biol 23(12):5108-5119. https://doi.org/10. 1111/gcb.13774

Willassen Y (1998) The stochastic rotation problem: a generalization of Faustmann's formula to stochastic forest growth. J Econ Dyn Control 22:573-596. https://doi.org/10.1016/S0165-1889(97) 00071-7

Woodruff DR, Meinzer FC, Lachenbruch B (2008) Height-related trends in leaf xylem anatomy and shoot hydraulic characteristics in a tall conifer: safety versus efficiency in water transport. New Phytol 180: 90-99. https://doi.org/10.1111/j.1469-8137.2008.02551.x

Yousefpour R, Hanewinkel M (2014) Balancing decisions for adaptive and multipurpose conversion of Norway spruce (Picea abies; L. karst) monocultures in the black forest area of Germany. For Sci 60(1):73-84. https://doi.org/10.5849/forsci.11-125

Yousefpour R, Hanewinkel M (2015) Forestry professionals' perceptions of climate change, impacts and adaptation strategies for forests in south-west Germany. Clim Chang 130(2):273-286. https://doi.org/ 10.1007/s10584-015-1330-5

Yousefpour R, Hanewinkel M, Le Moguédec G (2010) Evaluating the suitability of management strategies of pure Norway spruce forests in the black forest area of southwest Germany for adaptation to or mitigation of climate change. Environ Manag 45:387-402. https:// doi.org/10.1007/s00267-009-9409-2

Yousefpour R, Jacobsen JB, Thorsen BJ, Meilby H, Hanewinkel M, Oehler K (2012) A review of decision-making approaches to handle uncertainty and risk in adaptive forest management under climate change. Ann For Sci 69(1):1-15. https://doi.org/10.1007/s13595011-0153-4

Publisher's note Springer Nature remains neutral with regard to jurisdictional claims in published maps and institutional affiliations. 